\title{
PENGARUH AKTIVITAS ORGANISASI DAN KEMANDIRIAN BELAJAR TERHADAP PRESTASI BELAJAR BIOLOGI
}

\author{
Deden Ibnu Aqil \\ Dosen Program Studi Pendidikan Ekonomi Universitas Indraprasta PGRI \\ Email : Den.aqil@gmail.com
}

\begin{abstract}
Abstrak
Penelitian ini betujuan untuk mengetahui pengaruh aktivitas organisasi terhadap prestasi belajar biologi, mengetahui pengaruh antara kemandirian belajar terhadap prestasi belajar biologi dan mengatahui pengaruh aktivitas organisasi dan kemandirian belajar terhadap prestasi belajar biologi SMA di kecamatan Sawangan Depok. Metode penelitian yang digunakan adalah metode survey. Jumlah sampel 40 orang pengurus OSIS terdiri dari 26 siswa SMAN 5 Depok dan 14 Orang dari siswa SMA Islamiyah Sawangan Depok,. Pengumpulan data dilakukan dengan menggunakan teknik penyebaran angket. Analisa data meliputi analisis deskriptif, koefisien korelasi sederhana pearson, koefesien determinasi, dan koefisien jalur. Penelitian ini dilaksanakan pada bulan Nopember 2014 sampai dengan bulan Januari 2015. Hasil penelitian menunjukkan : (1) tidak terdapat pengaruh langsung yang signifikan aktivitas organisasi terhadap prestasi belajar biologi siswa ditunjukan oleh $t_{\text {hitung }}=1,218$ lebih kecil dari $t_{\text {tabel }}=2,026$ dengan koefesien jalur $=0,216$ (2) terdapat pengaruh langsung yang signifikan aktivitas organisasi terhadap kemandirian belajar ditunjukan oleh $\mathrm{t}_{\text {hitung }}=$ 2,838 lebih besar dari $t_{\text {tabel }}=2,026$ dengan koefesien jalur $=0,418$ (3) tidak tedapat pengaruh langsung yang signifikan kemandirian belajar terhadap prestasi belajar siswa ditujukan oleh thitung $=$ 0,016 lebih kecil dari $t_{\text {tabel }}=2,026$ dengan koefesien jalur $=0,093$ (4) tidak terdapat pengaruh tidak langsung aktivitas organisasi terhadap prestasi belajar biologi siswa melalui kemandirian belajar ditujukan oleh $t_{\text {hitung }}=1,115$ lebih kecil dari $t_{\text {tabel }}=2,026$ dengan koefesien jalur $=0,394$.
\end{abstract}

Kata kunci : aktivitas organisasi, kemandirian belajar, prestasi belajar biologi

\section{PENDAHULUAN}

Pendidikan berfungsi mengembangkan kemampuan peserta didik agar membentuk manusia yang bermartabat dalam rangka mencerdaskan kehidupan bangsa sebagaimana yang tertulis dalam Undang-Undang tersebut. Pengembangan kemampuan yang bermartabat merupakan hal yang sangat penting dihayati perkembangannya karena sangat berpengaruh dalam kehidupan sehari-hari.

Kehidupan masyarakat yang saat ini telah berkembang seiring pesatnya perkembangan sains dan teknologi, menuntut manusia untuk semakin bekerja keras menyesuaikan diri dalam segala aspek kehidupan. Salah satunya adalah aspek pendidikan yang sangat menentukan maju mundurnya suatu kehidupan yang semakin kuat persaingannya. Dengan demikian proses pendidikan diharapkan mampu membentuk manusia yang melek sains dan teknologi seutuhnya.

Hasil yang diharapkan dari proses belajar mengajar biologi ini adalah menjadikan siswa yang memiliki kepribadian peduli terhadap lingkungan hidup, maka pelajaran ini sangat penting untuk menjadi perhatian guru dan siswa karena salah satu penilaian keberhasilan dalam proses pembelajaran ini adalah dengan melihat hasil belajar siswa. Hasil belajar ini mungkin akan beragam dan juga menarik apabila dikaitkan dengan aktifitas siswa diluar kelas dan kemampuan belajar siswa untuk mandiri di rumah.

OSIS merupakan wadah bagi murid untuk melakukan kegiatan yang sesuai dengan bakat dan minatnya. Organisasi merupakan wadah bagi peserta didik untuk mengekspresikan diri sesuai dengan bakat dan minat yang dimilikinya. Partisipasi 
siswa dalam kegiatan OSIS justru dikhawatirkan akan mengganggu pengembangan kreativitas belajar siswa, karena siswa yang aktif mengikuti kegiatan organisasi sering mengalami kesulitan membagi waktu.

Siswa terlalu sibuk berorganisasi, sehingga sering meninggalkan pelajaran dan mengalami kesulitan untuk mengejar ketinggalan pelajaran. Seperti yang terjadi di SMA Waskito Pamulang, terdapat siswa yang aktif berorganisasi dan sering meninggalkan pelajaran, sehingga siswa tersebut tertinggal materi pelajaran. Hal ini tentunya tidak sejalan dengan tujuan kegiatan OSIS dan pengembangan kreativitas belajar siswa melalui partisipasi kegiatan OSIS tidak akan tercapai.

Dalam kegiatan OSIS siswa dapat memiliki kemampuan lebih dalam bersosialisasi, berinteraksi, baik dengan sesama siswa atau dengan orang lain dalam masyarakat. Mereka yang berorganisasi pasti mempunyai lebih banyak pengalaman dan mempunyai skill atau kemampuan yang cukup baik di banding siswa lain yang enggan mengikuti organisasi.

Kemandirian dalam belajar merupakan syarat mutlak bagi siswa guna mencapai hasil yang memuaskan. Kemandirian dalam belajar memberikan memberikan landasan yang kuat bagi keberhasilan studi untuk meraih prestasi. Masalah pokok yang paling banyak dihadapi oleh siswa adalah masalah belajar. Biasanya siswa memperoleh kesulitan dalam metode yang tepat bagi dirinya, kesulitan dalam mengatur waktu belajar dan sulit dalam membangkitkan minat untuk belajar sendiri atau mandiri yang antara lain disebabkan kurangnya fasilitas belajar dirumah bahkan karena aktivitas berorganisasi siswa disekolah dengan kegiatannya yang padat.

Mereka mengidentifikasi asumsi-asumsi mereka, menggunakan pemikiran kritis dan logis, dan mempertimbangankan penjelasan alternatif. Dengan cara ini para siswa aktif mengembangkan pelajaran tentang sains terutama pemahaman sains biologi. Dalam pelajaran ini siswa mengombinasikan pengetahuan mereka dengan keterampilan bernalar dan berpikirnya. Pelajaran ini menawarkan informasi ilmiah dan cara berpikir ilmiah untuk mengambil keputusan dan kepentingan orang banyak yang perlu di informasikan seperti, udara, air dan hutan. Pemahaman sains biologi dan kemampuan dalam mengaplikasikannya akan meningkatkan kapasitas siswa untuk memegang pekerjaan penting dan produktif di masa depan.

Dari tiga hal diatas kiranya penulis melihat bahwa keaktifan organisasi yang dilaksanakan siswa disekolah akan mempengaruhi hasil belajar biologi dan disamping mereka aktif berorganisasi (membutuhkan waktu untuk sampai meninggalkan kegiatan belajarnya) mengharuskan mereka untuk belajar mandiri di rumah. Maka peneliti membuat judul "Pengaruh Aktivitas Organisasi Siswa Dan Kemandirian Belajar Terhadap Prestasi Belajar Biologi “ (Survey Pada Sekolah Menengah Atas di Kecamatan Sawangan Kota Depok)

\section{TINJAUAN PUSTAKA}

\section{Hakikat keaktifan berorganisasi}

Menurut Poerwadarminto, (2006: 20) mengatakan bahwa Keaktifan berasal dari kata aktif yang artinya giat (bekerja, berusaha), kektifan adalah kesibukan atau salah satu kegiatan kerja yang dikerjakan atau dilaksanakan. Berdasarkan pendapat tersebut dapat di diartikan bahwa keaktifan adalah kegiatan 
atau aktivitas atau segala sesuatu yang dilakukan atau kegiatan yang terjadi baik fisik maupun non fisik. Aktivitas tidak hanya ditentukan oleh aktivitas fisik semata, tetapi juga ditentukan oleh aktivitas non fisik seperti mental, intelektual dan emosional.

Organisasi adalah unit sosial atau pengelompokkan manusia yang sengaja dibentuk dan dibentuk kembali dengan penuh pertimbangan dalam rangka mencapai tujuan-tujuan tertentu (Etzioni, 1982: 2). Organisasi adalah susunan dan aturan dari berbagai bagian (orang) sehingga merupakan kesatuan yang teratur. Akar kata ini mendapat awalan ber- sehingga menjadi kata berorganisasi yang artinya bergiat dalam organisasi, tersusun dan teratur.

\section{Hakikat Kemandirian Belajar}

Kemandirian adalah hal atau keadaan dapat berdiri sendiri tanpa bergantung pada orang lain (KBBI, 2008: 281). Menurut Dimyati (1998) sebagaimana yang dikutip oleh Indriani (2006: 34) kemandirian belajar dapat diartikan sebagai aktivitas belajar dan berlangsungnya lebih didorong oleh kemauan sendiri, pilihan sendiri dan tanggung jawab sendiri dari pembelajar.

Menurut Robert Ronger (1990: 93), seseorang dikatakan mandiri jika:1. Dapat bekerja sendiri secara fisik, 2. Dapat berpikir sendiri,3.. Dapat Menyusun ekspresi atau gagasan yang dimengerti orang lain, dan 4.Kegiatan yang dilakukan disahkan sendiri secara emosional.

\section{Pengertian Prestasi Belajar}

Prestasi belajar adalah produk akhir dari sebuah proses belajar. Kemampuan menggunakan pengetahuan dan konsep belajar merupakan dasar dalam peningkatan prestasi belajar siswa. Mengingat keberadaan tersebut prestasi belajar tidaklah berdiri sendiri namun ia melekat pada banyak faktor lain.

\section{METODOLOGI}

Penelitian dilaksanakan di Sekolah Menengah Atas (SMA) di wilayah Sawangan Kota Depok. Pemilihan tempat penelitian didasarkan atas kesesuaian antara tujuan penelitian dan karakteristik siswa. SMA yang dipilih di wilayah kecamatan Sawangan meliputi SMA 5 Negeri Depok dan SMA Islamiyah Sawangan Depok. Sesuai dengan perencanaan yang telah dirumuskan, penelitian dilaksanakan selama tiga bulan yang dilakukan pada bulan Nopember 2014 dan berakhir pada bulan Januari 2015.

Metode penelitian yang dipergunakan adalah metode survey, yaitu metode penelitian yang digunakan untuk mengungkap pengaruh antara variabel pengaruh aktivitas organisasi OSIS, kemandirian belajar dan prestasi belajar biologi siswa pada siswa Sekolah Menengah Atas yang berada di wilayah Sawangan di Kota Depok. Untuk mengetahui hubungan antar variabel dalam penelitian ini, peneliti menyusun hubungan antar variabel dalam bentuk diagram jalur berikut ini :

Pengambilan sampel dilakukan dengan mendata siswa/I yang menjadi pengurus OSIS Dari SMA yang ada di Kecamatan Sawangan, selanjutnya terpilih SMA Islamiyah dan SMAN 5 Depok. Sampel terdiri dari pengurus osis dari kelas X \& XI. Sebanyak 24 siswa dari SMAN 5 Depok dan 14 siswa dari SMA Islamiyah. Total sampel dalam kegiatan penelitian ini adalah 40 siswa. 
Research and Development Journal Of Education

Vol. 2 No. 2 April 2016

ISSN 2406-9744

HASIL DAN PEMBAHASAN

Uji normalitas

Aktivitas Organisasi

Tabel 1. U1ji normalitas aktivitas organisasi

\begin{tabular}{|c|c|c|}
\hline \multicolumn{3}{|c|}{ One-Sample Kolmogorov-Smirnov Test } \\
\hline & & $\begin{array}{l}\text { AKTV } \\
\text { ORGANISASI }\end{array}$ \\
\hline $\mathrm{N}$ & & 40 \\
\hline Normal Parameters ${ }^{\beth}$ & Mean & 67.25 \\
\hline & Std. Deviation & 7.348 \\
\hline Most Extreme Differences & Absolute & .194 \\
\hline & Positive & .096 \\
\hline & Negative & -.194 \\
\hline Kolmogorov-Smirnov $Z$ & & 1.228 \\
\hline Asymp. Sig. (2-tailed) & & .098 \\
\hline
\end{tabular}

a. Test distribution is Normal.

Interpretasi :

Dalam menginterpretasikan data hasil uji normalitas kita lihat kolom perhatian orang tua, Terdapat nilai Kosmogorov Smirnov $=1,228$ dengan probabilitas 0.842 (Asymp. Sig. (2-tailed)).

Persyaratan data berdistribusi normal jika probabilitas atau $p>0,05$ pada uji normalitas dengan Kolmogorov Smirnov. Oleh karena nilai $p=0,842$ atau $p>$ 0,05 , maka $\mathrm{H}_{0}$ diterima dan $\mathrm{H}_{1}$ ditolak. Artinya data perhatian orang tua berasal dari populasi yang berdistribusi normal.

\section{Kemandirian belajar}

Tabel 2. Uji normalitas kemandirian belajar

\begin{tabular}{|c|c|c|}
\hline \multicolumn{3}{|c|}{ One-Sample Kolmogorov-Smirnov Test } \\
\hline & & $\begin{array}{l}\text { KEMANDIRIA } \\
\text { N_BELAJAR }\end{array}$ \\
\hline$N$ & & 40 \\
\hline Normal Parameters ${ }^{2}$ & Mean & 72.40 \\
\hline & Std. Deviation & 7.001 \\
\hline Most Extreme Differences & Absolute & .096 \\
\hline & Positive & .061 \\
\hline & Negative & -.096 \\
\hline Kolmogorow-Smirnow Z & & .610 \\
\hline Asymp. Sig. (2-tailed) & & .851 \\
\hline
\end{tabular}

a. Test distribution is Normal.

Interpretasi :

Dalam menginterpretasikan data hasil uji normalitas kita lihat kolom perhatian orang tua, Terdapat nilai Kosmogorov Smirnov = 0,610 dengan probabilitas 0.754 (Asymp. Sig. (2-tailed)).

Persyaratan data berdistribusi normal jika probabilitas atau $p>0,05$ pada uji normalitas dengan Kolmogorov Smirnov. Oleh karena nilai $p=0.754$ atau $p>$ 0,05 , maka $\mathrm{H}_{0}$ diterima dan $\mathrm{H}_{1}$ ditolak. Artinya data perhatian orang tua berasal dari populasi yang berdistribusi normal. 
Research and Development Journal Of Education

Vol. 2 No. 2 April 2016

ISSN 2406-9744

\section{Prestasi belajar siswa}

Tabel 3. Uji normalitas prestasi belajar siswa

\begin{tabular}{|ll|r|}
\hline \multicolumn{2}{|c|}{ One-Sample Kolmogorov-Smirnow Test } \\
\hline & & $\begin{array}{c}\text { PRESTASI- } \\
\text { BELAJAR } \\
\text { BIO }\end{array}$ \\
\hline$N$ & & 40 \\
Normal Parameters ${ }^{2}$ & Mean & 80.28 \\
& Std. Deviation & 5.666 \\
Most Extreme Differences & Absolute & .119 \\
& Positive & .119 \\
Kolmogorov-Smirnov $Z$ & Negative & -.076 \\
Asymp. Sig. (2-tailed) & & .755 \\
\hline
\end{tabular}

a. Test distribution is Normal.

Interpretasi :

Dalam menginterpretasikan data hasil uji normalitas kita lihat kolom perhatian orang tua, Terdapat nilai Kosmogorov Smirnov $=0,775$ dengan probabilitas 0.619 (Asymp. Sig. (2-tailed)).

Persyaratan data berdistribusi normal jika probabilitas atau $\mathrm{p}>0,05$ pada uji normalitas dengan Kolmogorov Smirnov. Oleh karena nilai $p=0.619$ atau $p>0,05$, maka $\mathrm{H}_{0}$ diterima dan $\mathrm{H}_{1}$ ditolak. Artinya data perhatian orang tua berasal dari populasi yang berdistribusi normal.

Berdasarkan ketiga uji yang dilakukan di atas maka dapat disimpulkan bahwa data dari ketiga variabel penelitian menunjukan berdistribusi normal. Dengan demikian memenuhi syarat uji analisis parametrik.

\section{Uji Linieritas}

Uji Lineritas hubungan aktivitas organisasi OSIS dengan kemandirian belajar

Tabel 4. Uji Linieritas aktivitas organisasi OSIS dengan kemandirian belajar

ANOVA Table

\begin{tabular}{|c|c|c|c|c|c|c|c|}
\hline & & & $\begin{array}{l}\text { Sum of } \\
\text { Squares }\end{array}$ & df & Mean Square & $\mathrm{F}$ & Sig. \\
\hline \multirow{5}{*}{$\begin{array}{l}\text { KEMANDIRIAN BELAJAR } \\
\text { *AKTVORGANINSASI }\end{array}$} & \multirow[t]{3}{*}{ Between Groups } & (Combined) & 916.376 & 18 & 50.910 & 1.074 & .433 \\
\hline & & Linearity & 334.325 & 1 & 334.325 & 7.055 & .015 \\
\hline & & Deviation from Linearity & 582.051 & 17 & 34.238 & .722 & .750 \\
\hline & \multicolumn{2}{|l|}{ Within Groups } & 995.224 & 21 & 47.392 & & \\
\hline & \multicolumn{2}{|l|}{ Total } & 1911.600 & 39 & & & \\
\hline
\end{tabular}

Interpretasi :

Pada ANOVA tabel di bagian Deviation from Linierity menunjukkan hubungan antara aktivitas organisasi dengan kemandirian belajar nilai $\mathrm{F}=0.722$ dengan nilai probabilitas (kolom sig) $p=0,750$, Karena nilai signifikansi $p=0,750>$ 0,05 maka dengan demikian dapat disimpulkan $\mathrm{H}_{0}$ diterima dan $\mathrm{H}_{1}$ ditolak dan model regresi bersifat linier. 
Research and Development Journal Of Education

Vol. 2 No. 2 April 2016

ISSN 2406-9744

\section{Uji Lineritas hubungan aktivitas organisasi OSIS dengan prestasi belajar biologi siswa}

Tabel 5. Uji Linieritas aktivitas organisasi OSIS denganprestasi belajar siswa

\begin{tabular}{|c|c|c|c|c|c|c|c|}
\hline \multicolumn{8}{|c|}{ ANOVA Table } \\
\hline & & & $\begin{array}{l}\text { Sum of } \\
\text { Squares }\end{array}$ & $d f$ & Mean Square & $\mathrm{F}$ & Sig. \\
\hline \multirow{5}{*}{$\begin{array}{l}\text { PRESTASI BELAJARR } \\
\text { BI0*AKTV_ORGANISASI }\end{array}$} & \multirow[t]{3}{*}{ Between Groups } & (Combined) & 462.046 & 18 & 25.669 & .682 & .792 \\
\hline & & Linearity & 58.597 & 1 & 58.597 & 1.558 & .226 \\
\hline & & Deviation from Linearity & 403.449 & 17 & 23.732 & .631 & .831 \\
\hline & Within Groups & & 789.929 & 21 & 37.616 & & \\
\hline & Total & & 1251.975 & 39 & & & \\
\hline
\end{tabular}

Interpretasi :

Pada ANOVA tabel di bagian Deviation from Linierity menunjukkan hubungan antara aktivitas organisasi dengan kemandirian belajar nilai $\mathrm{F}=0.631$ dengan nilai probabilitas (kolom sig) $p=0,831$, Karena nilai signifikansi $p=0,831>$ 0,05 maka dengan demikian dapat disimpulkan $\mathrm{H}_{0}$ diterima dan $\mathrm{H}_{1}$ ditolak dan model regresi bersifat linier.

Uji Lineritas hubungan kemandirian belajar siswa dengan prsetasi belajar biologi siswa

Tabel 6. Uji Linieritas hubungan kemandirian belajar siswa dengan prestasi belajar biologi siswa

ANOVA Table

\begin{tabular}{|c|c|c|c|c|c|c|c|}
\hline & & & $\begin{array}{l}\text { Sum of } \\
\text { Squares }\end{array}$ & $d f$ & Mean Square & $\mathrm{F}$ & Sig. \\
\hline \multirow{5}{*}{$\begin{array}{l}\text { PRESTASI_BELAJAR_ } \\
\text { BIO* } \\
\text { KEMANDIRIAN_BELAJAR }\end{array}$} & Between Groups & (Combined) & 720.808 & 19 & 37.937 & 1.428 & .218 \\
\hline & & Linearity & 10.787 & 1 & 10.787 & .406 & .531 \\
\hline & & Deviation from Linearity & 710.021 & 18 & 39.446 & 1.485 & .195 \\
\hline & Within Groups & & 531.167 & 20 & 26.558 & & \\
\hline & Total & & 1251.975 & 39 & & & \\
\hline
\end{tabular}

Interpretasi :

Pada ANOVA tabel di bagian Deviation from Linierity menunjukkan hubungan antara kemandirian belajar dengan Prestasi Belajar Biologi menghasilkan nilai $\mathrm{F}=1,485$ dengan nilai probabilitas (kolom sig) $\mathrm{p}=0,195$, Karena nilai signifiknasi $\mathrm{p}=0,195>0,05$ maka dengan demikian $\mathrm{H}_{0}$ diterima dan $\mathrm{H}_{1}$ ditolak dan dapat disimpulkan bahwa regresi bersifat linier.

\section{Uji Kolinearitas}

Tabel 7. Uji Kolinieritas

\begin{tabular}{|ll|r|c|}
\hline \multirow{2}{*}{} & \multicolumn{2}{|c|}{ Collinearity Statistics } \\
\cline { 3 - 4 } Model & Tolerance & \multicolumn{1}{c|}{ V|F } \\
\hline $1 \quad$ & (Constant) & & \\
& AKTV_ORGANISASI & .825 & 1.212 \\
& KEMANDIRIAN_BELAJARR & .825 & 1.212 \\
\hline
\end{tabular}


Research and Development Journal Of Education

Vol. 2 No. 2 April 2016

Dari tabel hasil uji kolinieraitas diperoleh nilai tolerance 0,825 masih di bawah angka 1 dan VIF 1,212 mendekati angka 1. maka terdapat dugaan bebas dari kolinieritas antara variabel aktivitas organisasi dengan kemandirian belajar.

\section{Pengujian Hipotesis Penelitian}

Pengujian Hipotesis

\section{Analisis Korelasi}

Tabel 8. Rangkuman Hasil Koefisien Korelasi

\begin{tabular}{|c|c|c|c|c|}
\hline \multicolumn{5}{|c|}{ Correlations } \\
\hline & & $\begin{array}{l}\text { AKTV } \\
\text { ORGANISASI }\end{array}$ & $\begin{array}{l}\text { KEMANDIRIA } \\
\text { NBBLA,JAR }\end{array}$ & $\begin{array}{l}\text { PRESTASI- } \\
\text { BELAJAR_- } \\
\text { BIO }\end{array}$ \\
\hline \multirow[t]{3}{*}{ AKTV_ORGANISASI } & Pearson Correlation & 1 & $.418^{\prime \prime}$ & .216 \\
\hline & Sig. (2-tailed) & & .007 & .180 \\
\hline & $N$ & 40 & 40 & 40 \\
\hline \multirow[t]{3}{*}{ KEMANDIRIAN_BELAJAAR } & Pearson Correlation & $.418^{\prime \prime}$ & 1 & .093 \\
\hline & Sig. (2-tailed) & .007 & & .569 \\
\hline & $\mathrm{N}$ & 40 & 40 & 40 \\
\hline \multirow{3}{*}{$\begin{array}{l}\text { PRESTASI_BELAJAR_ } \\
\text { BIO }\end{array}$} & Pearson Correlation & .216 & .093 & 1 \\
\hline & Sig. (2-tailed) & .180 & .569 & \\
\hline & $\mathrm{N}$ & 40 & 40 & 40 \\
\hline
\end{tabular}

*. Correlation is significant at the 0.01 level (2-tailed).

Analisis Jalur berikut :

Dari perhitungan yang didapat dimasukan ke dalam diagram jalur sebagai

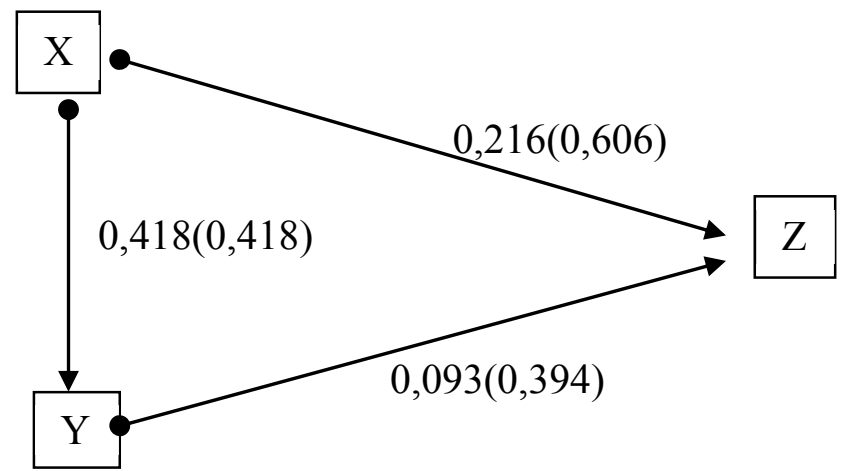

Gambar 1. Koefisien Korelasi antar Variable dan Koefisien Jalur

Keterangan : Angka diluar kurung koefisien korelasi, di dalam kurung koefisien jalur.

Pengujian Hipotesis Kesatu

Tabel 9. Persamaan garis regresi $\mathrm{X}$ dan $\mathrm{Y}$ atas $\mathrm{Z}$

\begin{tabular}{|c|c|c|c|c|c|c|}
\hline \multirow[b]{2}{*}{ Mode } & & \multicolumn{2}{|c|}{ Unstandardized Coefficients } & \multirow{2}{*}{$\begin{array}{c}\begin{array}{c}\text { Standardized } \\
\text { Coefficients }\end{array} \\
\text { Beta } \\
\end{array}$} & \multirow[b]{2}{*}{$t$} & \multirow[b]{2}{*}{ Sig. } \\
\hline & & $B$ & Std. Error & & & \\
\hline \multirow[t]{3}{*}{1} & (Constant) & 68.951 & 10.612 & & 6.498 & .000 \\
\hline & AKTV_ORGANISASI & .166 & .136 & .215 & 1.218 & .231 \\
\hline & KEMANDIRIAN_BELAJJAR & .002 & .143 & .003 & .016 & .987 \\
\hline
\end{tabular}

a. DependentVariable: PRESTASI_BELAJAR_BIO 
Untuk $\alpha=0,05$ dan $\mathrm{dk}=\mathrm{n}-\mathrm{k}-1=40-2-1=37$ pada uji dua pihak diperoleh nilai $t_{\text {tabel }}=t_{h}=1,218$, Karena nilai $T_{h}<T_{t}(1,218<2,026)$ maka berdasarkan kriteria pengujian diatas dinyatakan bahwa $\mathrm{H}_{0}$ diterima dan dapat disimpulkan bahwa tidak terdapat pengaruh langsung yang signifikan aktivitas organisasi terhadap Prestasi Belajar Biologi Siswa.

Pengujian Hipotesis Kedua

Tabel 10. Persamaan garis regresi $\mathrm{X}$ dan $\mathrm{Y}$ atas $\mathrm{Z}$.

\begin{tabular}{|c|c|c|c|c|c|c|}
\hline \multirow[b]{2}{*}{ Made } & & \multicolumn{2}{|c|}{ Unstandardized Coefficients } & \multirow{2}{*}{$\begin{array}{c}\begin{array}{c}\text { Standardized } \\
\text { Coefficients }\end{array} \\
\text { Beta }\end{array}$} & \multirow[b]{2}{*}{$t$} & \multirow[b]{2}{*}{ Sig. } \\
\hline & & B & Std. Error & & & \\
\hline \multirow[t]{3}{*}{1} & (Constant) & 68.951 & 10.612 & & 6.498 & .000 \\
\hline & AKTV_ORGANISASI & .166 & .136 & .215 & 1.218 & .231 \\
\hline & KEMANDIRIAN_BEELAJAR & .002 & .143 & .003 & .016 & .987 \\
\hline
\end{tabular}

a. Dependent Variable: PRESTASI_BELAJAR_BIO

Untuk $\alpha=0,05$ dan $\mathrm{dk}=\mathrm{n}-\mathrm{k}-1=40-2-1=37$ pada uji dua pihak diperoleh nilai $t_{\text {tabel }}=t_{h}=0,016$, Karena nilai $\mathrm{T}_{\mathrm{h}}<\mathrm{T}_{\mathrm{t}}(0,016<2,026)$ maka berdasarkan kriteria pengujian diatas dinyatakan bahwa $\mathrm{H}_{0}$ diterima dan dapat disimpulkan bahwa tidak terdapat pengaruh langsung yang signifikan kemandirian belajar terhadap Prestasi Belajar Biologi Siswa.

Pengujian Hipotesisi Ketiga

Tabel 11. Persamaan garis regresi $X$ atas $Y$

\begin{tabular}{|c|c|c|c|c|c|c|}
\hline \multicolumn{7}{|c|}{ Coefficients ${ }^{\mathrm{s}}$} \\
\hline \multirow[b]{2}{*}{ Madel } & & \multicolumn{2}{|c|}{ Unstandardized Coefficients } & \multirow{2}{*}{$\begin{array}{c}\begin{array}{c}\text { Standardized } \\
\text { Coefficients }\end{array} \\
\text { Beta } \\
\end{array}$} & \multirow[b]{2}{*}{$t$} & \multirow[b]{2}{*}{ Sig. } \\
\hline & & $B$ & Std. Error & & & \\
\hline & (Constant) & 45.602 & 9.497 & & 4.802 & .000 \\
\hline & AKTV_ORGANISASI & .398 & .140 & .418 & 2.838 & .007 \\
\hline
\end{tabular}

a. Dependent Variable: KEMANDIRIAN_BELAJAR

Untuk $\alpha=0,05$ dan $\mathrm{dk}=\mathrm{n}-\mathrm{k}-1=40-2-1=37$ pada uji dua pihak diperoleh nilai $\mathrm{t}_{\text {tabel }}=\mathrm{t}_{\mathrm{h}}=2,838$, Karena nilai $\mathrm{T}_{\mathrm{h}}>\mathrm{T}_{\mathrm{t}}(2,838>2,026)$ maka berdasarkan kriteria pengujian diatas dinyatakan bahwa $\mathrm{H}_{1}$ diterima dan dapat disimpulkan bahwa terdapat pengaruh langsung yang signifikan aktivitas organisasi terhadap kemandirian belajar.

Pengujian Hipotesis Keempat

Berdasarkan analisis jalur diketahui bahwa koefisien jalur variabel aktivitas organisasi terhadap prestasi belajar biologi melalui kemandirian belajar $\mathrm{p} 123=\mathrm{p} 21$ x p32 $=0.418 \times 0,394=0,165$. Jika dibandingkan dengan nilai p31, maka nilai $\mathrm{p} 123=0,165<\mathrm{p} 31=0.606$. hal ini menginterpretasikan bahwa variabel intervening tidak berpengaruh secara signifikan terhadap prestasi belajar.

Dari perhitungan SPSS 16 dan Microsoft excel sebagai berikut :

Untuk $\alpha=0,05$ dan $\mathrm{dk}=\mathrm{n}-\mathrm{k}-1=40-2-1=37$ pada uji dua pihak diperoleh nilai $t_{\text {tabel }}=t_{h}=2,026$, Karena nilai $T_{h}<T_{t}(1,115<2,026)$ maka 
berdasarkan kriteria pengujian diatas dinyatakan bahwa $\mathrm{H}_{0}$ diterima dan dapat disimpulkan bahwa : tidak terdapat pengaruh tidak langsung yang signifikan aktivitas organisasi terhadap Prestasi Belajar Biologi Siswa melalui kemandirian belajar.

\section{SIMPULAN DAN SARAN \\ Simpulan}

Dari hasil pengolahan data yang telah dilakukan pada bab sebelumnya, maka dihasilkan beberapa temuan sebagai berikut :

1. Aktivitas organisasi tidak memiliki pengaruh langsung yang signifikan terhadap Prestasi Belajar Biologi. Nilai koefisien korelasi sebesar dengan KD $=4.665 \%$. Hasil uji hipotesis didapatkan $t_{\text {hitung }}$ sebesar 1,218 lebih kecil dari $t_{\text {tabel }}$ sebesar 2,026, artinya $\mathrm{H}_{0}$ diterima dan $\mathrm{H}_{1}$ ditolak. Berdasarkan temuan penelitian ini dapat disimpulkan bahwa "Aktivitas organisasi tidak berpengaruh secara langsung dan signifikan terhadap pretasi belajar biologi siswa" dapat diterima.

2. Kemandirian belajar tidak memiliki pengaruh langsung yang signifikan terhadap hasil prestasi belajar siswa. Nilai koefisien korelasi sebesar dengan $\mathrm{KD}=0.864$ $\%$. Hasil uji hipotesis didapatkan $t_{\text {hitung }}$ sebesar 0,016 lebih kecil dari $t_{\text {tabel }}$ sebesar 2,026, artinya $\mathrm{H}_{0}$ diterima dan $\mathrm{H}_{1}$ ditolak. Berdasarkan temuan penelitian ini dapat disimpulkan bahwa "Kemandirian belajar tidak berpengaruh secara langsung dan signifikan terhadap prestasi belajar biologi siswa" dapat diterima.

3. Aktivitas organisasi berpengaruh langsung dan signifikan terhadap kemandirian belajar. Nilai koefisien korelasi sebesar dengan $\mathrm{KD}=17,47 \%$. Hasil uji

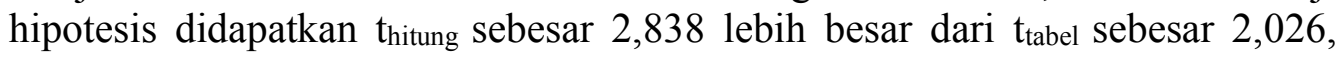
artinya $\mathrm{H}_{0}$ ditolak dan $\mathrm{H}_{1}$ diterima. Berdasarkan temuan penelitian ini dapat disimpulkan bahwa "Aktivitas organisasi memiliki pengaruh langsung dan signifikan terhadap kemandirian belajar" dapat diterima.

4. Aktivitas organisasi tidak memiliki pengaruh tidak langsung terhadap prestasi belajar biologi siswa melalui kemandirian belajar. Nilai koefisien korelasi sebesar dengan $\mathrm{KD}=3.88 \%$. Hasil uji hipotesis didapatkan thitung sebesar 1,115 lebih kecil dari tabel sebesar 2,026, artinya $\mathrm{H}_{0}$ diterima dan $\mathrm{H}_{1}$ ditolak. Berdasarkan temuan penelitian ini dapat disimpulkan bahwa "aktivitas organisasi tidak memiliki pengaruh langsung dan signifikan terhadap prestasi belajar siswa, melalui kemandirian belajar" dapat diterima.

\section{Saran-saran}

Berdasarkan temuan penelitian di atas maka peneliti menyarankan kepada para guru umumnya dan guru Biologi khususnya:

1. Karena aktivitas organisasi dapat mempengaruhi peningkatan kemandirian belajar siswa, maka aktivitas organisasi OSIS harus ditingkatkan di sekolah.

2. Dengan meningkatkan aktivitas organisasi, maka akan memiliki dampak langsung terhadap kemandirian belajar, yang kemudian akan muncul pada diri anak sikap positif dan termotivasi dalam belajar, sehingga dapat meningkatkan prestasi belajar. 
Research and Development Journal Of Education

Vol. 2 No. 2 April 2016

ISSN 2406-9744

\section{UCAPAN TERIMA KASIH}

Dengan ini penulis mengungkapkan rasa syukur kepada Allah SWT yang telah memberikan rahmat dan hidayah-Nya, serta penulis mengucapkan terima kasih kepada semua pihak yang telah membantu penulis menyelesaikan kegiatan penulisan ini.

\section{DAFTAR PUSTAKA}

Al Khalili Abdussalam. 2005. Mengembangkan Kreativitas Anak. Jakarta: Pustaka Al-Kautsar.

Bloom, B., et.al. 1956. Taxonomi of Educational Objectives : cognitive domain book. New York : Longman.

Dedi Supriyadi. 2000. Kreativitas Kebudayaan dan Perkembangan IPTEK. Bandung: Alfabeta.

Etzioni, Amitai. 1982. Modern organization (Organisasi-organisasi modern). Jakarta: UI-Press Yusuf LN.

Goodman and Smart. 1999. Emotional Intelligence. New York: Bantam Books.

Hayati Y. 2008. Perilaku Organisasi. Bandung : Alfabeta.

Hakim, Thursan. 2007. Belajar Secara Efektif. Jakarta : Niaga Swadaya

Oemar Hamalik. 1990. Metode Belajar dan Kesulitan-kesulitan Belajar. Jakarta: Gramedia.

Poerwodarminto,W.J.S. 2006. Kamus Umum Bahasa Indonesia. Edisi Ketiga. Jakarta: Balai Pustaka.

Sardiman. 1997. Cara-cara Belajar yang Efektif. Yogyakarta: UGM Press.

Sudjana. N. 1999. Penelitian Hasil Proses Belajar Mengajar. Bandung : Remaja Rosdakarya.

Sugiyono. 2010. Metode Penelitian Pendidikan Kuantitatif dan $R \& D$. Bandung: Alfabeta.

Slameto. 1997. Belajar dan Faktor-Faktor yang Mempengaruhinya. Jakarta: Rineka Cipta.

Syamsul dan Nurihsan Juntika, A. 2008.Teori kepribadian. Bandung: PT Remaja Rosdaka. 
Research and Development Journal Of Education

Vol. 2 No. 2 April 2016

ISSN 2406-9744

Undang-undang Nomor 14 Tahun 2005 \& Peraturan Pemerintah RI Nomor 74 Tahun 2008 Tentang Guru dan dosen, (Bandung: Penerbit Citra Umbara, 2009), hal.64 